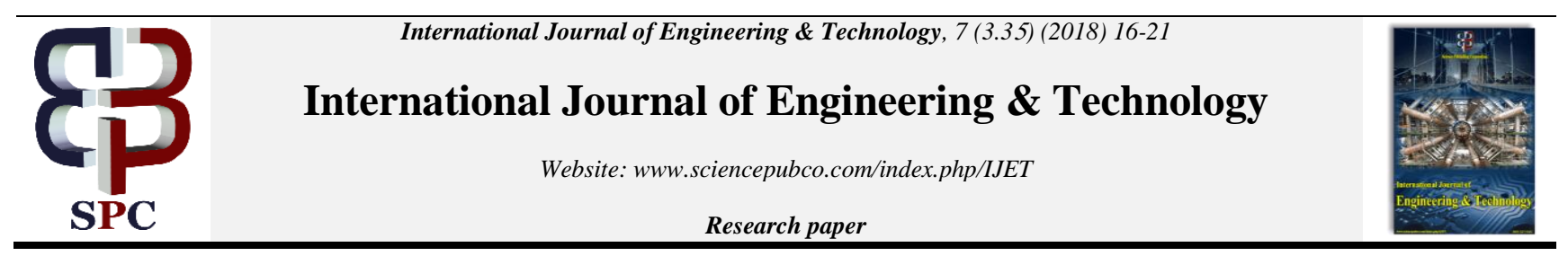

\title{
Durability Behavior of Self Compacting Concrete Made with Recycled Concrete Aggregate
}

\author{
T.V. Arul Prakash*1, Dr. M. Natarajan ${ }^{2}$, Dr. T. Senthil Vadivel $^{3}$, Dr.V.Karthik ${ }^{4}$ \\ ${ }^{1}$ Research Scholar, Department of Civil Engineering, Karpagam Academy of Higher Education, Coimbatore-641021, Tamilnadu, India \\ ${ }^{2}$ Professor, Department of Civil Engineering, Karpagam Academy of Higher Education, Coimbatore-641021, Tamilnadu, India \\ ${ }^{3}$ Professor \& Head, Department of Civil Engineering, School of Engineering \& Technology, Adamas University, Kolkata - 700126. West \\ Bengal. ${ }^{4}$ Professor, Department of Civil Engineering, SRK Institute of Technology, Vijayawada-521108. Andhra Pradesh.
}

*Email: tsnsenthu@rediffmail.com

\begin{abstract}
This article presents the influence of the Recycled Concrete Aggregate (RCA) on the durability behavior of self-compacting fly ash concrete (M30 Grade). The RCA from local construction demolition site wereemployed as a replacement for natural coarse aggregate $(0 \%-30 \%)$ in self-compacting concrete(SCC). The Viscosity modifying material used in this study was Class F fly ash. Different kinds of tests were conducted on the concrete specimens such as water absorption test, sulphate attack, chloride attack, carbonation test,sorptivity test, etc., When the durability behavior was taken into consideration,the summary of results indicate that recycled concrete aggregate different percentage of replacements as the optimal percentagein the manufacture of SCC without much affecting strength and durability.
\end{abstract}

Keywords: Recycled aggregates, Self compacting concrete, Durability parameters.

\section{Introduction}

Self-compacting or consolidating concrete is one of the extraordinaryand innovative developments in the construction field recently. The main benefit of using SCC in construction, it will run at its own weight without the need for vibration required for placement and compaction with overburdened reinforcement and complexity of the formwork. In view of these potential benefits, this method has been applicable in many countries in building construction and construction.

RCA uses concrete demolition materials and calcined clay masonry aggregates.Reuse of demolition waste disposal and isalso helpful in reducing the gap between the demand and supply of crushedgranite fresh aggregate. RCA from construction demolition site may be replaced in whole or in part by natural aggregates in the manufacture of SCC. The use of concrete waste as a coarse aggregate (CA)reduces the emission of $\mathrm{CO}_{2}(15-20 \%)$ by reducing the utilization of lime stone by $60 \%^{[1]}$. While the amount of demolition waste materialsgenerated in India has not yet been quantified properly, it is thought thatpresently the yearly rate of demolition of buildings and other structures in themajor cities has reached one to $2 \%$.Therefore, though the research on RCA in concrete is going on for past 70 years, the use of recycled aggregate (RA) is of great importance to save resources, to protect the environment and to achieve sustainable development in the construction sector ${ }^{[2]}$.

\section{Literature reviewed}

Ravindrajah (1987) describes the main problems in the demolition of concrete structures. The demolition of old buildings is on the rise, either because they are outdated, dangerous, need to be repaired and rehabilitated, or to allow the construction of new larger and larger structures. As a result, a large amount of concrete demolition is generated as waste and disposed of by landfill or landfill. Transport costs and the lack of landfills, however, make disposal a major problem.

Dhir (1999) investigates the ability of recycled aggregates (ACR) to be used in BS 5328 mixtures. Results on aggregate properties have shown that smooth concrete and reinforced concrete residues can be milled with existing equipment. to provide RCA with physical properties that meet the current requirements of BS882.

Prakash (2006) discusses many practices in the concrete industry that pose a potential threat to our environment and give rise to grave concern. Alongside the increase in consumption, the volume of waste from companies using concrete is increasing.

N R Gayawala (2011) obtained maximum compressive strength by adding amount of fly ash by $15 \%$ and for tensile strength they also got maximum tensile strength by adding $15 \%$ amount of fly ash in self-compacting concrete they also found that SCC had good durability properties than normal concrete. For flexural strength and pull out strength addition of $15 \%$ of fly ash in mix is enough for maximum strength.

Edwin Fernando (2014) carried out an experimental investigation on SCC by replacing the fly ash as a filler material and copper slag as 
river sand at a percentage of $5-25 \%$. Mix design is done as per EFNARC specification by keeping w/c ratio of 0.40 and super plasticizer was used to increase the flow ability. The result shows a marginal improvement at $40 \%$ fly ash replacement.

The use of recycled aggregates in the production of new concrete has gradually increased from an environmental and economic point of view. Nevertheless, there arevery few details related to the quality of recycled concrete is available. Hence, in this study an attempt was made tounderstand the durabilitybehavior of self-compacting concretewithRCA.

\section{Materials used}

The physical and chemical properties of the materials used in this studyare cited in Table 1 and Table 2.

a. Cement - OPC 53

b. Viscosity modifier (VMA) - Class F fly ash.

c. Fine aggregate - Natural river sand

d. Coarse aggregate - Locally available granite crushed stones passing through $20 \mathrm{~mm}$ sieve and retained on $12.5 \mathrm{~mm}$

e. Super plasticizers -Conplast 420 of $3.5 \%$ was used

f. Recycled Concrete Aggregate - It was acquired from the demolished construction waste and concrete cubes which are more angular and higher absorption capacity.

g. Mix Proportions - Mix design was made to produce M30 grade SCC.

Table 1: Physical properties

\begin{tabular}{|c|c|c|c|c|c|c|}
\hline \multicolumn{2}{|c|}{ Parameter } & Cement & Fly ash & Fine aggregate & Coarse aggregate & $\begin{array}{c}\text { Recycled } \\
\text { concrete } \\
\text { aggregate }\end{array}$ \\
\hline \multicolumn{2}{|c|}{ Color } & Greenish grey & Dark grey & - & - & - \\
\hline \multicolumn{2}{|c|}{ Specific gravity } & 3.13 & 2.10 & 2.55 & 2.75 & 2.44 \\
\hline \multicolumn{2}{|c|}{ Fineness $\left(\mathrm{m}^{2} / \mathrm{kg}\right)$} & 310 & 425 & 2.56 & - & - \\
\hline \multicolumn{2}{|c|}{ Fineness modulus } & - & - & - & 6.95 & 6.55 \\
\hline Setting time & Initial (Min) & 43 & - & - & - & - \\
\hline \multicolumn{2}{|c|}{ Bulk density $\left(\mathrm{kg} / \mathrm{m}^{3}\right)$} & - & 1157 & 1885 & 1485 & 1246 \\
\hline \multicolumn{2}{|c|}{ Water absorption (\%) } & - & - & 1.40 & 0.80 & 3.45 \\
\hline
\end{tabular}

Table 2: Chemical Properties of OPC 53 and Fly ash

\begin{tabular}{|c|c|c|c|c|c|c|c|c|}
\hline Component & $\mathrm{SiO}_{2}$ & $\overline{\mathrm{Fe}_{2} \mathrm{O}_{3}}$ & $\mathrm{SO}_{3}$ & $\mathrm{Na}_{2} \mathrm{O}$ & $\mathrm{K}_{2} \mathrm{O}$ & MgO & $\mathbf{A l}_{2} \mathbf{O}_{3}$ & $\mathrm{CaO}$ \\
\hline
\end{tabular}

Table 3: Concrete Mix Proportions $\left(\mathrm{kg} / \mathrm{m}^{3}\right)$

\begin{tabular}{|c|c|c|c|c|c|c|c|}
\hline Description & $\begin{array}{c}\text { RCA replacement } \\
\text { \% }\end{array}$ & Cement & Fine Aggregate & $\begin{array}{c}\text { Coarse } \\
\text { Aggregate }\end{array}$ & $\begin{array}{c}\text { Recycled } \\
\text { concrete } \\
\text { aggregate }\end{array}$ & $\begin{array}{c}\text { VMA } \\
\text { (Fly ash) }\end{array}$ & $\begin{array}{c}\text { Water } \\
\text { agher| }\end{array}$ \\
\hline SCC & 0 & 310 & 910 & 890 & 8 & 138 & 185 \\
\hline RCASCC05 & 5 & 310 & 910 & 845 & 45 & 138 \\
\hline RCASCC10 & 10 & 310 & 910 & 801 & 89 & 138 & 185 \\
\hline RCASCC15 & 15 & 310 & 910 & 756 & 134 & 138 & 185 \\
\hline RCASCC20 & 20 & 310 & 910 & 712 & 178 & 138 & 185 \\
\hline RCASCC25 & 25 & 310 & 910 & 667 & 223 & 138 & 185 \\
\hline RCASCC30 & 30 & 310 & 910 & 623 & 267 & 138 & 185 \\
\hline
\end{tabular}

\section{Experimental investigation}

\subsection{Fresh and Hardened properties of SCC}

M30 grade self-compacting concrete was produced by partially replacing natural aggregates with recycled concrete aggregates. The concrete has been freshly examined and hardened. SCC is characterized by its flow, passing and resistance to separation. The concrete mix has recently been tested in accordance with EFNARC recommendations and strength of concrete cubes under compression was listed in Table 4 and Table 5.

Table 4: Fresh properties of SCC

\begin{tabular}{|c|c|c|c|c|c|}
\hline \multirow{2}{*}{ Description } & Slump flow (mm) & T50cm Slump (Sec) & V-Funnel (Sec) & L-Box (H1/H2) & $\begin{array}{c}\text { J-Ring } \\
\text { (H1-H2) }\end{array}$ \\
\hline EFNARC & $650-800$ & $2-5$ & $6-12$ & $0.8-1.0$ & 0 \\
\hline SCC & 770 & 2.4 & 6.9 & 0.9 & 4 \\
\hline RCASCC05 & 752 & 2.49 & 7.15 & 0.91 & 4.5 \\
\hline RCASCC10 & 731 & 2.64 & 7.3 & 0.92 & \\
\hline RCASCC15 & 708 & 2.67 & 7.4 & 0.93 & \\
\hline RCASCC20 & 694 & 2.73 & 7.65 & 0.9 & 7 \\
\hline RCASCC25 & 678 & 2.8 & 7.88 & 0.94 & 8 \\
\hline RCASCC30 & 660 & 2.93 & 8.1 & 0.94 & 8.5 \\
\hline
\end{tabular}


Table 5 - Compressive strength

\begin{tabular}{|c|c|c|c|c|}
\hline \multirow{2}{*}{ Description } & \multicolumn{4}{|c|}{ Compressive strength in N/mm $\mathbf{~}^{\mathbf{2}}$} \\
\cline { 2 - 5 } & $\mathbf{3}$ days & $\mathbf{7}$ days & $\mathbf{1 4}$ days & 32.4 \\
\hline SCC & 12.87 & 26.51 & 36.83 & 36.27 \\
\hline RCASCC05 & 12.71 & 26.35 & 32.03 & 36.55 \\
\hline RCASCC10 & 12.54 & 26.22 & 31.92 & 36.37 \\
\hline RCASCC15 & 12.38 & 26.1 & 31.75 & 36.11 \\
\hline RCASCC20 & 12.21 & 25.99 & 31.68 & 35.99 \\
\hline RCASCC25 & 12.19 & 25.9 & 30.79 & 35.22 \\
\hline
\end{tabular}

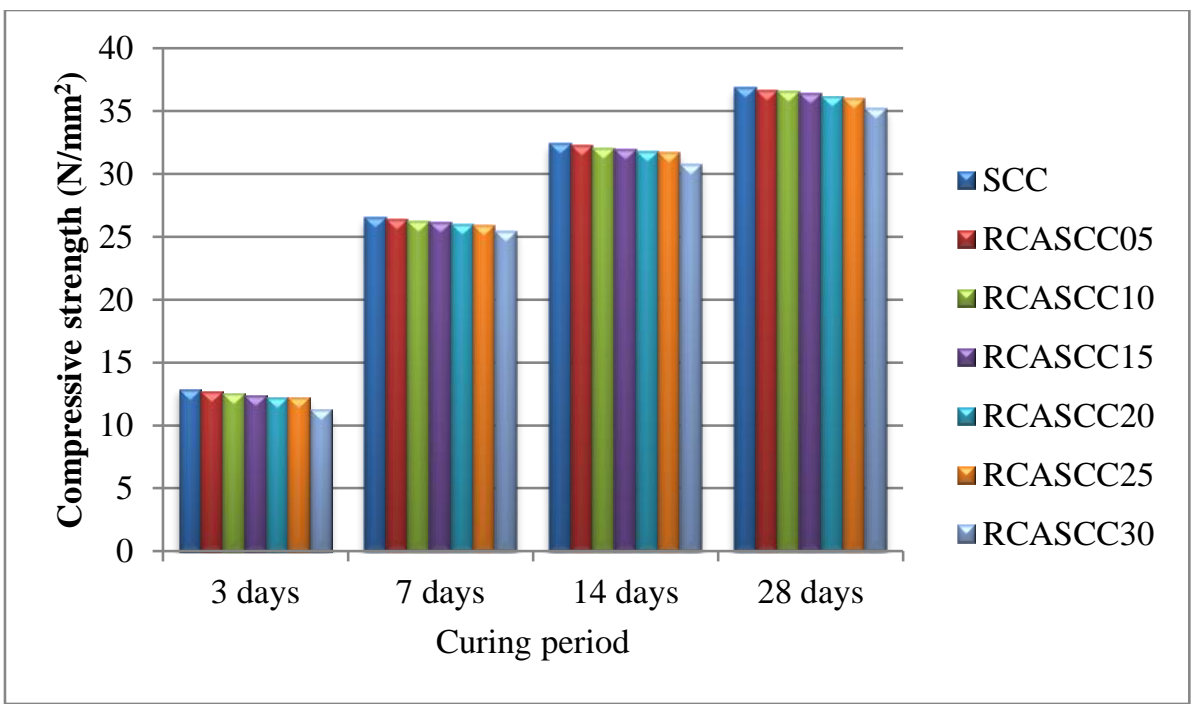

Figure 1: Compressive strength

\subsection{Durability Properties}

The following are the various tests were conducted on self compacting concrete made by recycled concrete aggregate (SCC-
RCA) with different percentage of replacing natural coarse aggregate. The test results are cited in Tables 6 to 12 and Figure 2 to 9.

\subsubsection{Water absorption test}

Table 6: Water Absorption results

\begin{tabular}{|c|c|c|c|c|c|c|}
\hline \multirow{2}{*}{ Description } & \multicolumn{2}{|c|}{ Weight of Concrete cubes (kg) } & \multicolumn{2}{|c|}{ Amount of water absorption } & \multicolumn{2}{c|}{ Density (kg/m $\left.\mathbf{m}^{\mathbf{3}}\right)$} \\
\cline { 2 - 6 } & Dry & Wet & Grams (g) & Percentage (\%) & Dry & Wet \\
\hline SCC & 8.165 & 8.591 & 426 & 5.22 & 2419.26 & 2545.48 \\
\hline RCASCC55 & 8.201 & 8.651 & 450 & 5.49 & 2429.93 & 2563.26 \\
\hline RCASCC10 & 8.287 & 8.767 & 480 & 5.79 & 2455.41 & 2597.63 \\
\hline RCASCC15 & 8.305 & 8.812 & 507 & 6.10 & 2460.74 & 2610.96 \\
\hline RCASCC20 & 8.308 & 8.822 & 514 & 6.19 & 2461.63 & 2613.93 \\
\hline RCASCC25 & 8.379 & 8.896 & 517 & 6.17 & 2482.67 & 2635.85 \\
\hline RCASCC30 & 8.398 & 8.916 & 518 & 6.17 & 2488.30 & 2641.78 \\
\hline
\end{tabular}

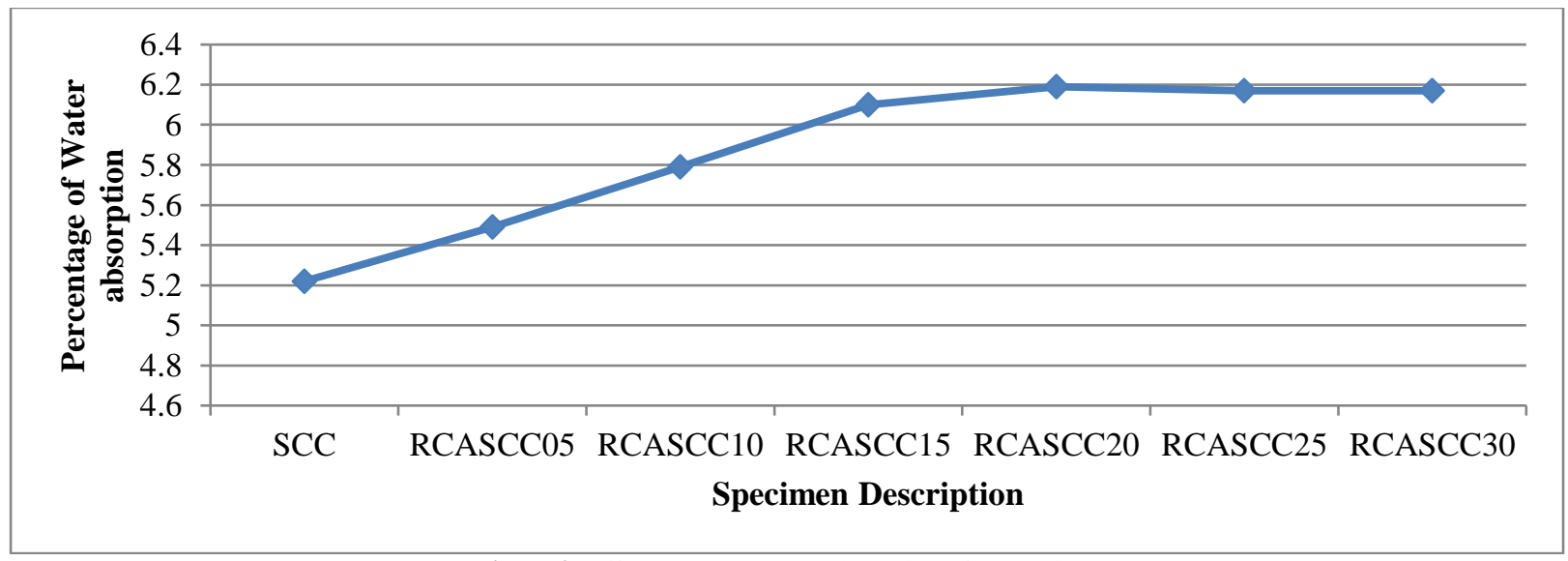

Figure 2: Effect RCA on Water absorption of SCC mixes 


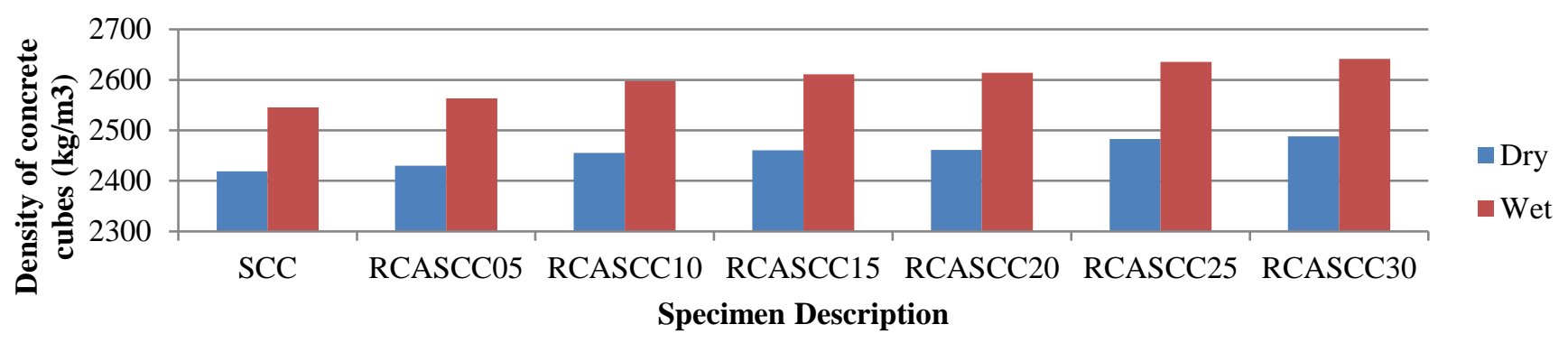

4.2.2. Sorptivity test

Sorptivity of concretesamples weretested after 28days of curing.

Table 7:Effect of RCA on sorptivity on SCC Description Sorptivity $\left(\mathrm{mm}^{3} / \mathrm{mm}^{2} / \mathrm{min}^{0.5}\right)$ 28 days

\begin{tabular}{|c|c|c|}
\hline SCC & 0.065 & 0.058 \\
\hline RCASCC05 & 0.077 & 0.060 \\
\hline RCASCC10 & 0.087 & 0.064 \\
\hline RCASCC15 & 0.104 & 0.079 \\
\hline RCASCC20 & 0.112 & 0.091 \\
\hline RCASCC25 & 0.139 & 0.111 \\
\hline RCASCC30 & 0.168 & 0.134 \\
\hline
\end{tabular}

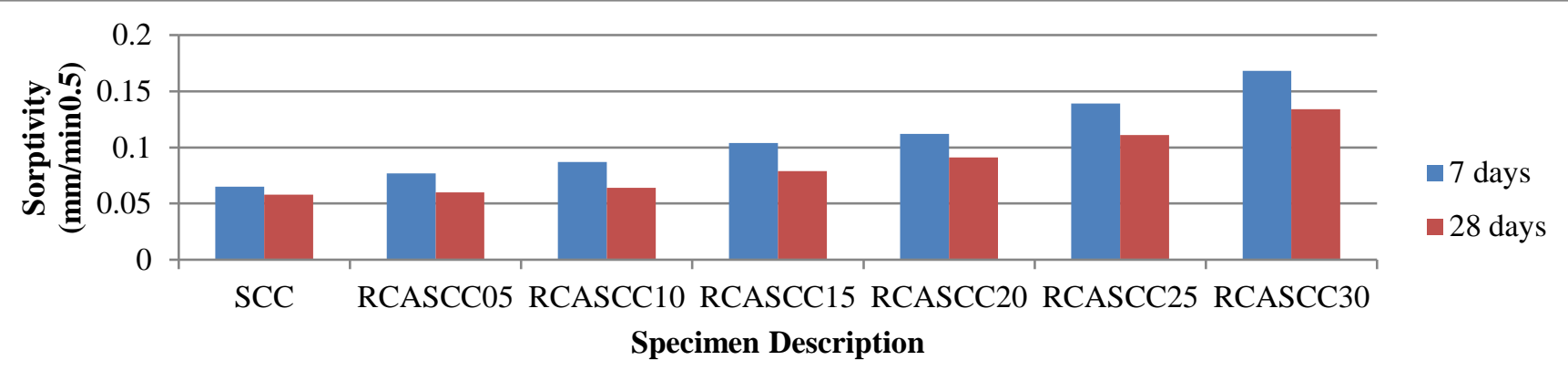

Figure 4: Sorptivity results

\subsubsection{Accelerated Carbonation Test}

The accelerated carbonation test on SCC-RCA specimens were measured as per the guidelines mentioned in ISO 1920-12:2015

Table 8: Carbonation test results

\begin{tabular}{|c|c|c|c|c|c|c|c|c|c|}
\hline \multicolumn{5}{|c|}{ Table 8: Carbonation test results } & RCASCC25 & 14 & 20 & 21 & 24 \\
\hline \multirow{2}{*}{ Description } & \multicolumn{4}{|c|}{ Carbonation depth (mm) } & RCASCC 30 & 12 & 18 & 20 & 21 \\
\hline & 4 weeks & 8 weeks & 12 weeks & 16 weeks & & & & & \\
\hline
\end{tabular}

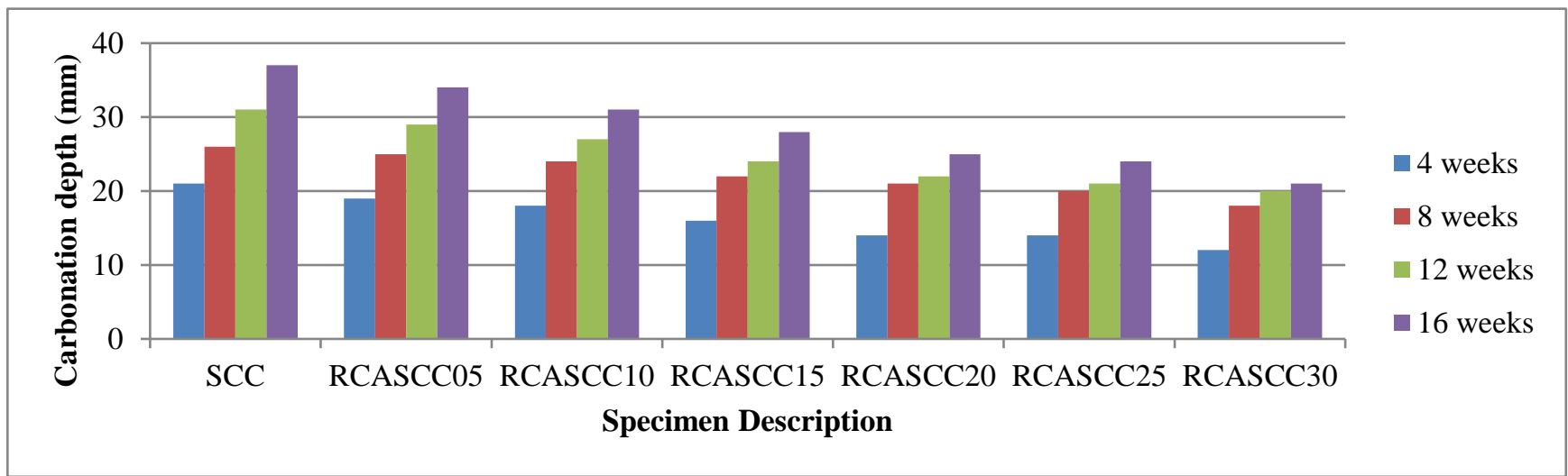

Figure 5: Carbonation test results

\subsubsection{Ultrasonic pulse velocity(UPV) test}

The UPV of SCC-RCA specimens were measured as per the guidelines mentioned in IS 13311 - Part 1.
Table 10: Velocity of Ultrasonic waves at various curing ages

\begin{tabular}{|c|c|c|c|c|}
\hline \multirow{2}{*}{ Description } & \multicolumn{4}{|c|}{ Ultrasonic pulse velocity (m/sec) } \\
\cline { 2 - 5 } & 3 days & $\mathbf{7 ~ d a y s}$ & $\mathbf{1 4}$ days & $\mathbf{2 8}$ days \\
\hline SCC & 4217 & 4366 & 4565 & 4717 \\
\hline RCASCC05 & 4316 & 4415 & 4601 & 4769 \\
\hline RCASCC10 & 4368 & 4497 & 4655 & 4852 \\
\hline
\end{tabular}




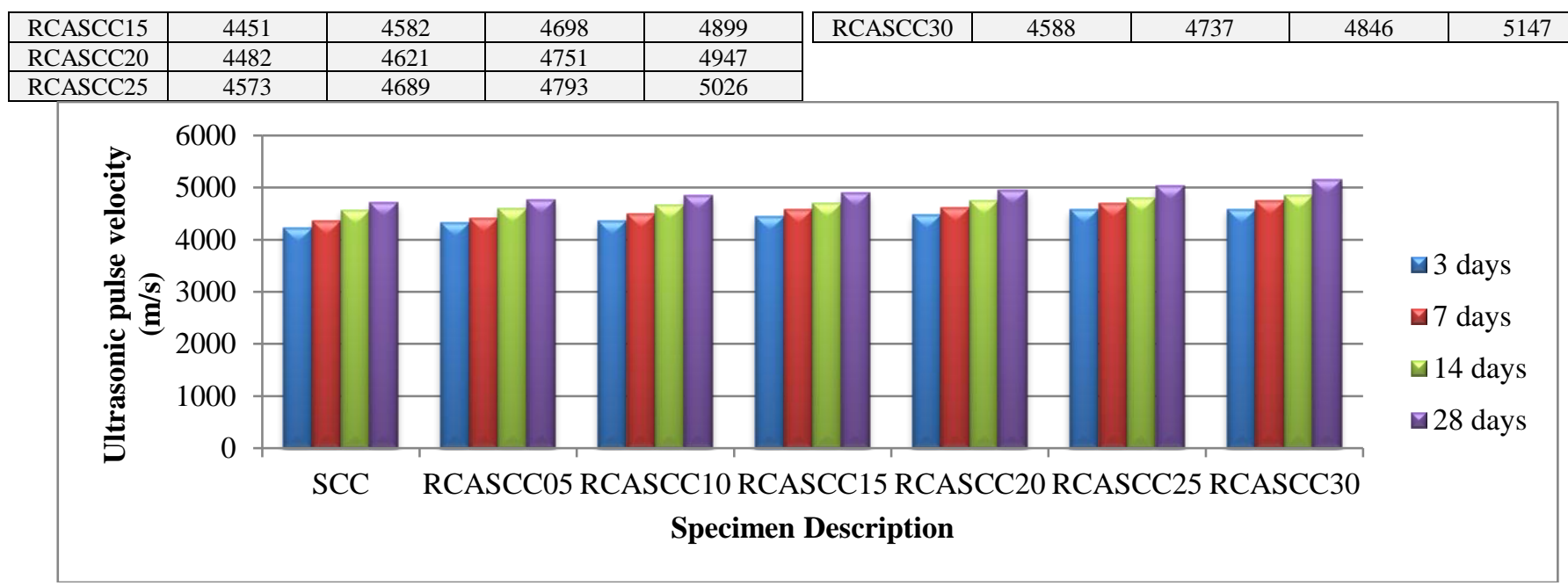

Figure 8: Ultrasonic pulse velocity results

\subsubsection{Sulphate attack test}

The test was conducted in $5 \% \mathrm{Na}_{2} \mathrm{SO}_{4}$ solution for a period of 28 days after initial water curing of 28 days. A remarkable gain in mass was achieved on SCC-RCS specimens, when they are exposed to sulphate environment for 28 days.

Table 9: Effect of RCA on SCC under sulphate attack

\begin{tabular}{|c|c|c|c|c|c|c|c|c|}
\hline \multirow{2}{*}{ Description } & \multicolumn{2}{|c|}{ Mass of concrete cubes } & \multicolumn{2}{|c|}{ Change in mass content } & \multicolumn{2}{|c|}{ Compressive strength $\left(\mathrm{N} / \mathrm{mm}^{2}\right)$} & \multicolumn{2}{|c|}{ Loss of compressive strength } \\
\hline & Before $\left(\mathbf{W}_{1}\right)$ & $\operatorname{After}\left(\mathbf{W}_{2}\right)$ & $\left(W_{1}-W_{2}\right)$ & $\%$ & Before $\left(\sigma_{1}\right)$ & After $\left(\sigma_{2}\right)$ & $\left(\sigma_{1}-\sigma_{1}\right)$ & $\%$ \\
\hline RCASCC05 & 8.201 & 8.224 & 0.023 & 0.280 & 36.6 & 34.79 & 1.81 & 4.95 \\
\hline RCASCC15 & 8.305 & 8.344 & 0.039 & 0.470 & 36.37 & 34.28 & 2.09 & 5.75 \\
\hline RCASCC20 & 8.308 & 8.359 & 0.051 & 0.614 & 36.11 & 34.02 & 2.09 & 5.79 \\
\hline RCASCC25 & 8.379 & 8.476 & 0.097 & 1.158 & 35.99 & 33.89 & 2.1 & 5.83 \\
\hline RCASCC 30 & 8.398 & 8.658 & 0.26 & 3.096 & 35.22 & 32.86 & 2.36 & 6.70 \\
\hline
\end{tabular}

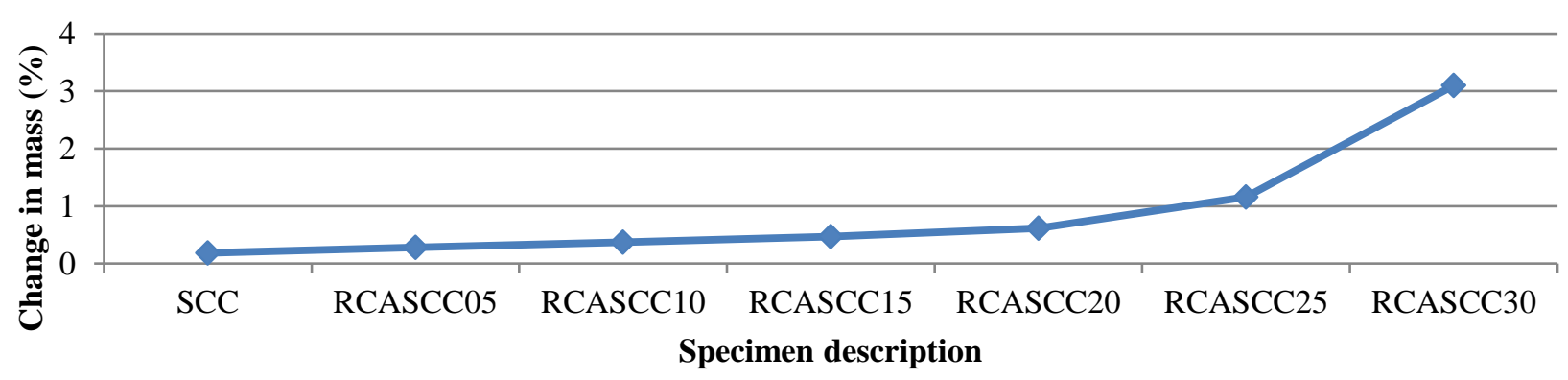

Figure 6: Change in mass after sulphate exposure

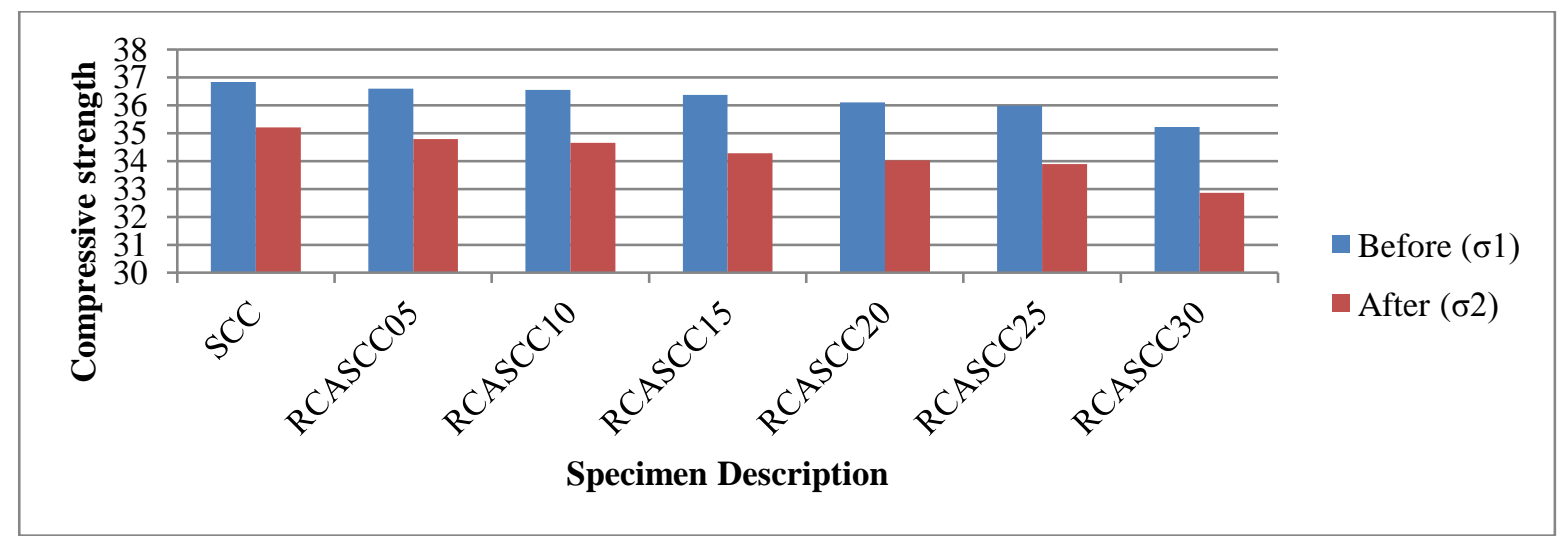

Figure 7: Change in compressive strength after sulphate exposure 


\subsection{6. $\quad$ Rapid Chloride Permeability Test (RCPT)}

The RCPT test on the SCC-RCA samples were done as per ASTM C1202.

Table 13: Chloride Ion Permeability test results

\begin{tabular}{|c|c|c|c|}
\hline Description & $\begin{array}{c}\text { Duration } \\
\text { (Minutes) }\end{array}$ & $\begin{array}{c}\text { Charge Passed } \\
\text { (Coulombs) }\end{array}$ & $\begin{array}{c}\text { Chloride Ion } \\
\text { Permeability as per }\end{array}$ \\
\hline
\end{tabular}

\begin{tabular}{|c|c|c|c|}
\hline & & & ASTM 1202-97 \\
\hline SCC & 30 & 3740 & Moderate \\
\hline RCASCC05 & 30 & 3812 & Moderate \\
\hline RCASCC10 & 30 & 3875 & Moderate \\
\hline RCASCC15 & 30 & 3921 & Moderate \\
\hline RCASCC20 & 30 & 3987 & Moderate \\
\hline RCASCC25 & 30 & 4159 & High \\
\hline RCASCC30 & 30 & 4320 & High \\
\hline
\end{tabular}

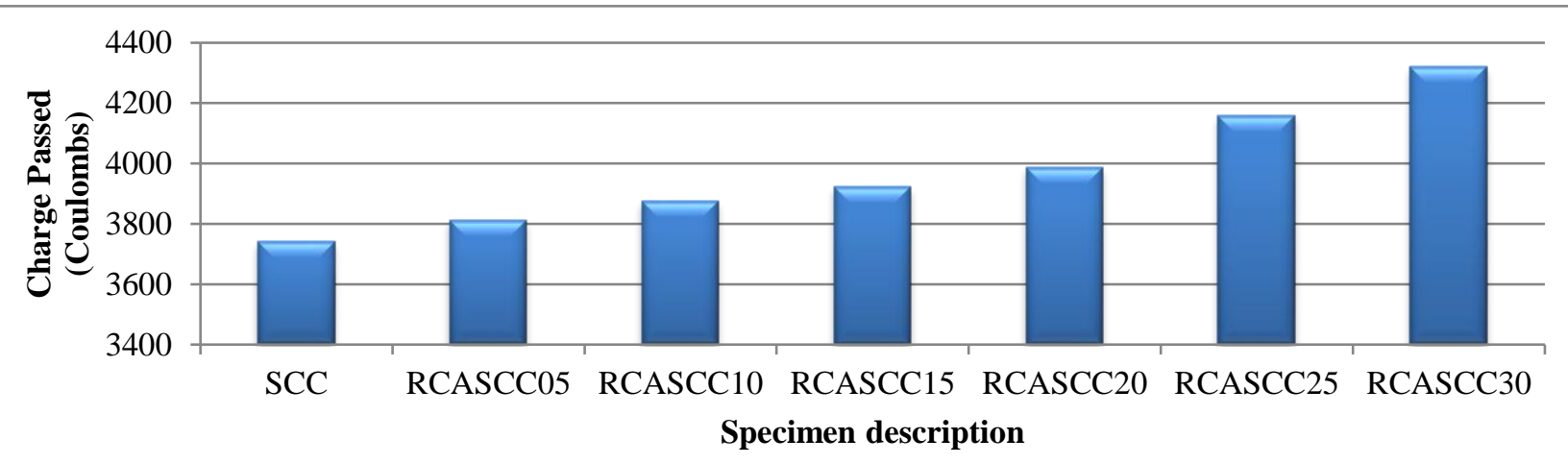

Figure 9: Chloride Ion Permeability test results

\section{Results and discussions}

The results show that the when RCA partly replaced for coarse aggregate, a sustainable concrete could be manufactured.

Self-compacting concrete manufactured with RCA has reached the target strength in all mixtures and meets the guidelines given in the EFNARC specifications.

There was a reduction in the strength properties by increasing the amount of RCA replacement in SCC at all ages of curing thought the optimum results were identified at $20-25 \%$.

The carbonation test results on the SCC-RCAshows reduction in carbonation depth while increasing the percentage of RCA.

The water absorption and sorptivity of SCC-RCA shows higher water absorption and sorptivity than conventional SCC.

The SCC-RCA results on UPV test, shows good quality indicating that there was not much influence on the quality of concrete by using RCA as course aggregate.

SCC-RCA was not preferred to use in marine environment. Because they are subjected to high amount of chloride ion permeation than the conventional SCC.

\section{References}

[1] J.J. Xiao, W.G. Li, Y.H. Fan, X. Huang, (2012), "An overview of study on recycled aggregate concrete in China (1996-2011)," Constr. Build. Mater. 31, pp. 364-383.

[2] P.J. Gluzhge, (1946), "The work of scientific research institute," GidrotekhnicheskoyeStroitel'stvo 4 pp. 27-28.

[3] EFNARC (2002), "Specification and guidelines for self-compacting concrete," European Federation of Producers and Applicators of Specialist Products for Structures.

[4] AloiaSchwartzentruber L.D, Le Roy R. and Cordin J, (2006) "Rheological behaviour of fresh cement pastes formulated from a Self Compacting Concrete (SCC)," Cement and Concrete Composites , vol. 36, pp. 12031213.

[5] E. Anastasiou, K. Georgiadis Filikas, M. Stefanidou., (2014). "Utilization of fine recycled aggregates in concrete with fly ash and steel slag," Construction and Building Materials, vol. 50, pp. 154-161.
[6] C. Marthong and T. P. Agrawal, (2012), "Effect of Fly Ash Additive on Concrete Properties," International Journal of Engineering Research and Applications (IJERA), ISSN: 2248-9622, vol. 2, Issue 4, pp. 1986-1991.

[7] R. Anuradha, v. sreevidya, r. venktasubramani and B. V Rangan (2012) "Modified guidelines for geopolymer concrete mix design using Indian Standards," Asian Journal of Civil Engineering, vol. 13, no. 3, pp. 353364.

[8] Malhotra V,M., (2002), "Introduction: Sustainable development and concrete technology," ACI Concrete International, vol. 24, no.7.

[9] Dhir, R.K., Limbachya, M.C., and Leelawat, T., (1999), "Suitability of recycled Concrete Aggregates in concrete," Magazine of Concrete Research, vol. 52, no. 4, pp. $235-242$.

[10] Prakash, K.B., and Manjunath, M. (2006), "Effect of replacement of natural aggregates by recycled aggregates on properties of concrete," Materials and structures, vol. 82, no. 7, pp $320-330$.

[11] Ravindrarajah, M., (1987), "Suitability of recycled concrete aggregates for use in concrete," Journal of the Institution of Engineers (India), vol. 14, pp. $34-40$.

[12] Zoran., (2008), "Properties of Self Compacting Concrete Different Types of Additives," Architecture and Civil Engineering, vol. 6, no. 2, pp. 173177.

[13] Pai. B.H.V., (2014), "Experimental Study on Self Compacting Concrete Containing Industrial By products," European Scientific Journal, vol. 10, no. 12 , pp. 292-300.

[14] Gritsada Sua-iam, NattMakul., (2013), "Use of recycled alumina as fine aggregate replacement in Self-Compacting concrete," Construction and Building Materials, vo. 47, pp. 701-710.

[15] Paratibha Aggarwal., (2008), "Self Compacting Concrete - Procedure for Mix Design.," Leonardo Electronic Journal of Practices and Technologies, vol. 12, pp. 15-24.

[16] Hui Zhaoa, Wei Svun, Xiaoming Wub and Bo Gao., (2015), "The properties of the Self-Compacting concrete with fly ash and ground granulated blast furnace slag mineral admixtures," Journal of Cleaner Production, vol. 1, pp. 25-34.

[17] Mucteba Uysal, Mansur Sumer., (2011), "Performance of self compacting concrete containing different mineral admixtures," Construction and Building Materials, vol. 25. No. 11, pp. 4112-4120.

[18] Edwin Fernando, Vandana C.J, Indu.G.nair, (2014), "Experimental investigation of self-compacting concrete with copper slag," International Journal of Engineering Research and Applications (ISSN:2248-9622), pp. 92-97.

[19] Anant Patel, Prashant Bhuva, Elizabeth George, Darshana Bhatt, (2011), "Compressive strength and Modulus of Elasticity of self compacting concrete," National conference on Recent trends in Engineering andTechnology.

[20] M. Iyappan and Dr. A. Jagannathan, (2014), "High strength self compacting concrete with nano silica," International Journal of Emerging Trendsin Engineering and Development, vol 5, Issue 4, pp. 163-168. 